\title{
Current status of diversity and distribution of Bryophytes of Odisha
}

\author{
Manorama Mishra, ${ }^{1}$ Prasad Kumar Dash,,$^{2 *}$ Afroz Alam, ${ }^{3}$ Santilata Sahoo ${ }^{1}$ and Ritarani Das ${ }^{1}$ \\ ${ }^{1}$ P.G.Department of Botany, Utkal University, Bhubaneswar, Odisha \\ ${ }^{2}$ Odisha Biodiversity Board, Department of Forest and Environment, Govt. of Odisha \\ ${ }^{3}$ Department of Bioscience and Biotechnology, Banasthali Vidyapith, (Rajasthan), India
}

\section{Article history}

Received: 19 March 2016

Accepted: 08 April 2016

Published: 09 June 2016

(C) Mishra et al. (2016)

Special Section: New Frontiers in Cryptogamic Botany

Section Editor

Afroz Alam

\section{Publisher}

Horizon e-Publishing Group

Corresponding Author

Prasad Kumar Dash

$\square_{\text {prasad.dash2008@gmail.com }}$

\begin{abstract}
In an attempt to reveal the biodiversity status of one of the least studied plant groups of Eastern Ghats, the authors have catalogued the diversity and distribution of bryoflora of Odisha situated in the Northern Eastern Ghats biogeographic regions of India. One hundred fourty nine species of bryophytes including 102 mosses under 23 families, 41 liverworts under 16 families and 6 hornworts under 2 families were reported from Odihsa as a result of 7 years of primary survey (2008-2015) conducted in some selected bryodiversity rich habitats covering 12 districts of Odisha and also from scrutiny of different research publications including research papers, books and research reports. In terms of species richness, the Deomali hills was found to be the most diverse in terms of bryophytes followed by Similipal biosphere reserve, Mahendragiri hills, Niyamgiri hills, Baphlimali hills and Khandadhar hills. Deomali hills also showed highest diversity in endemic mosses. Five mosses such as Fissidens orishae Gangulee, Erpodium mangiferae Müll. Hal., Hyophila comosa Dixon, Stereophyllum confusum Ther., Neckeropsis exserta (Hook. ex Schwagr.) Broth. are found to be endemic to India that occur in Odisha. Aneura pinguis (L.) Dumort., Anoectangium stracheyanum Mitt., Cyathophorella hookeriana (Griff.) M. Fleisch., Cyathophorum adiantum (Griff.) Mitt., Distichophyllum schmidtii Broth., Eurhynchium striatulum (Spruce) Schimp., Hypnum cupressiforme Hedw., Leucobryum juniperoideum (Brid.) Müll. Hal., Lophocolea bidentata (L.) Dumort., Macromitrium sulcatum (Hook.) Brid., Notothylas levieri Schiffner, Pallavicinia lyellii (Hook.) Gray Pellia epiphylla (L.) Corda., Philonotis fontana (Hedw.) Brid., Pogonatum neesii (Müll. Hal.) Dozy., Polytrichum commune Hedw., Polytrichum juniperinum Hedw., Racopilum cuspidigerum (Schwagr.) Angstrom, Racopilum orthocarpum Wilson ex Mitt., Riccia beyrichiana Hampe ex Lehm., Riccia billardieri Mont. \& Nees., Spruceanthus semirepandus (Nees) Verd., Thuidium cymbifolium (Müll. Hal.) Paris, Thuidium koelzii H. Rob., Trematodon longicollis Michx., are some of the new distributional record of occurrence for the Eastern Ghats.The present study reveals that Fissidentaceae, Pottiaceae, Bryaceae, Dicranaceae, Aytoniaceae, Marchantiaceae, Funariaceae and Anthocerotaceae are dominant families in the study area. The authors have also identified few forest pockets and critical habitat in the state where bryophyte diversity shall be very rich that needs a detailed survey in near future. The authors discuss the list of bryophytes of the state in a regional context of rarity, as well as address some general subject matters regarding cryptogam conservation and further work needed in the state of Odisha. The study would provide a prelude data for future bryological studies and bryomonitoring in the Eastern Ghats in general and the state of Odisha in particular.
\end{abstract}

\section{Keywords}

Bryophytes; Diversity; Eastern Ghats; Odisha; Similipal

Mishra, M., P. K. Dash, A. Alam, S. Sahoo and R. Das. 2016. Current status of diversity and distribution of Bryophytes of Odisha. Plant Science Today 3(2): 186-194. http://dx.doi.org/10.14719/pst.2016.3.2.222

\section{Introduction}

The bryophytes which comprise liverworts, hornworts, and mosses are widely distributed, generally dominate in between the altitude 10008000 meters and they are important components of the vegetation in many regions of the world. 
Table 1: Checklist of Bryophytes of Odisha

\begin{tabular}{lll}
\hline Name of the species & Family & Distribution in Odisha \\
\hline Hornworts & & \\
\hline Anthoceros angustus Steph. (Plate 1: Fig.29) & Anthocerotaceae & KJR, Khandadhar;SGD, Khandadhar, KPT, Deomali \\
Anthoceros levis L. (Plate 1: Fig.31) & Anthocerotaceae & All sites \\
Anthoceros punctatus L. & Anthocerotaceae & MBNJ, Similipal \\
Notothylas levieri Schiffn., (Plate 1: Fig.30) & Notothyladaceae & KRD, Barbara RF \\
Phaeoceros laevis (L.) Prosk. & Notothyladaceae & All sites \\
Phaeoceros laevis subsp. carolinianus & Notothyladaceae & MBNJ, Similipal \\
\hline
\end{tabular}

\section{Liverworts}

Aneura pinguis (L.) Dumort.

Asterella khasiana (Griff.) Grolle

Asterella angusta (Steph.) Pande, K.P.

Srivast. \& Sultan Khan (Plate 1: Fig.7)

Asterella blumeana (Nees) Pande, K.P. Srivast. \& Sultan Khan

Asterella wallichiana (Lehm.) Grolle (Plate 1: Aytoniaceae Fig.8)

Cephalozia connivens (Dicks.) Lindb.

Cephaloziaceae

Conocephalum conicum (L.) Underw.

Conocephalaceae

Cyathodium cavernarum Kunze (Plate 1:

Fig.1)

Dumortiera hirsuta (Sw.) Nees (Plate 1: Fig.6) Marchantiaceae

Frullania muscicola Steph.

Frullania squarrosa Gottsche

Heteroscyphus argutus (Nees) Schiffn.

Lejeunea discreta Lindenb.

Lophocolea bidentata (L.) Dumort.

Marchantia linearis Lehm. \& Lindenb.

Marchantia palmata Reinw., Nees \& Blume (Plate 1: Fig.4)

Marchantia polymorpha $\mathrm{L}$.

Metzgeria decipiens (C. Massal.) Schiffn. (Plate 1: Fig.5)

Metzgeria furcata (L.) Corda

Metzgeria himalayensis Kash.

Pallavicinia lyellii (Hook.) Gray (Plate 1: Fig.13)

Pellia endiviifolia (Dicks.) Dumort.

Pellia epiphylla (L.) Corda

Plagiochasma appendiculatum Lehm. \& Lindenb. (Plate 1: Fig.9)

Plagiochasma rupestre (G. Forst.) Steph.

Plagiochila porelloides (Torr.) Lindenb.

Plagiomnium rostratum (Schrad.) T.J. Kop.
Jubulaceae

Jubulaceae

Lophocoleaceae

Lejeuneaceae

Lophocoleaceae

Marchantiaceae

Marchantiaceae

Marchantiaceae

Metzgeriaceae

Metzgeriaceae

Metzgeriaceae

Pallaviciniaceae

Pelliaceae

Pelliaceae

Aytoniaceae

Aytoniaceae

Plagiochilaceae

Aytoniaceae
KPT, Deomali

MGR, Chitrakonda

RGD, Baphlimali, GPT, Mahendragiri

MBNJ, Similipal, RGD, Baphlimali

MBNJ, Similipal, RGD, Baphlimali

KJR, Khandadhar

MBNJ, Similipal, KHND, Karlapat, RGD, Baphlimali

All sites

KJR, Khandadhar, KHND, Karlapat, BGD, Gandhamardan, MBNJ, Similipal

KJR, Khandadhar

KJR, Khandadhar

KHND, Karlapat, KJH, Khandadhar

RGD, Baphlimali

KJR, Khandadhar, MBHJ, Similipal

MBNJ, Similipal

MBNJ, Similipal

MBNJ, Similipal

KPT, Deomali

GPT, Mahendragiri

MBNJ, Similipal, KJR, Khandadhar

KJR, Khandadhar

RGD, Baphlimali

RGD, Baphlimali, KPT, Deomali

All sites

MBNJ, Similipal, RGD, Baphlimali

Epiphyte on trees at Mahendragiri, Deomali

KPT, Deomali 
Table 1: Checklist of Bryophytes of Odisha (Contd.)

\begin{tabular}{|c|c|c|}
\hline Name of the species & Family & Distribution in Odisha \\
\hline \multicolumn{2}{|c|}{$\begin{array}{l}\text { Plagiothecium denticulatum (Hedw.) Schimp.Aytoniaceae } \\
\text { (Plate 1: Fig.17) }\end{array}$} & KPT, Deomali, MBNJ, Similipal, GPT, Debgiri \\
\hline Riccardia levieri Schiffn. & Aneuraceae & $\begin{array}{l}\text { KHND, Karlapat, KJH, Khandadhar, RGD, } \\
\text { Baphlimali, GJM, Budhakhol }\end{array}$ \\
\hline Riccia beyrichiana Hampe ex Lehm. & Ricciaceae & GPT, Mahendragiri \\
\hline Riccia fluitans L. & Ricciaceae & All sites \\
\hline Riccia pathankotensis Kash. & Ricciaceae & MGR, Chitrkonda \\
\hline $\begin{array}{l}\text { Riccia billardieri Mont. \& Nees. (Plate 1: } \\
\text { Fig.3) }\end{array}$ & Ricciaceae & MGR, Chitrkonda \\
\hline Riccia crystallina L. (Plate 1: Fig.2) & Ricciaceae & MGR, Chitrkonda \\
\hline Riccia discolor Lehm. \& Lindenb. & Ricciaceae & MBNJ, Similipal \\
\hline Riccia frostii Austin & Ricciaceae & KPT, Deomali \\
\hline Riccia glauca L. & Ricciaceae & $\begin{array}{l}\text { KPT, Deomali, GPT, Mahendragiri, MGR, } \\
\text { Chitrakonda }\end{array}$ \\
\hline Riccia trichocarpa M. Howe & Ricciaceae & KJR, Khandadhar \\
\hline $\begin{array}{l}\text { Spruceanthus semirepandus (Nees) Verd. } \\
\text { (Plate 1: Fig.12) }\end{array}$ & Lejeuneaceae & GPT, Mahendragiri \\
\hline Targionia hypophylla L. (Plate 1: Fig.10) & Targioniaceae & AGL, Satkosia, MBNJ, Similipal, AGL \\
\hline Targionia indica Udar \& A. Gupta & Targioniaceae & RGD, Baphlimali \\
\hline
\end{tabular}

\begin{tabular}{|c|c|c|}
\hline \multicolumn{3}{|l|}{ Mosses } \\
\hline $\begin{array}{l}\text { Aerobryopsis longissima (Dozy \& Molk.) M. } \\
\text { Fleisch }\end{array}$ & Meteoriaceae & KHND, Karlapat \\
\hline Anoectangium stracheyanum Mitt. & Pottiaceae & $\begin{array}{l}\text { KPD, Deomali; GPT, Mahendragiri, KJR, } \\
\text { Khandadhar }\end{array}$ \\
\hline Anoectangium walkeri Broth. & Pottiaceae & MBNJ, Similipal, KHND, Karlapat \\
\hline Barbula arcuata Griff. & Pottiaceae & RGD, Baphlimali \\
\hline $\begin{array}{l}\text { Barbula javanica Dozy \& Molk. (Plate 1: } \\
\text { Fig.2) }\end{array}$ & Pottiaceae & MBNJ, Similipal \\
\hline $\begin{array}{l}\text { Brachymenium exile (Dozy \& Molk.) Bosch \& } \\
\text { Sande Lac. }\end{array}$ & Bryaceae & KPT, Deomali \\
\hline Brachymenium microstomum Harv. & Bryaceae & KPT, Deomali \\
\hline Brachythecium rutabulum (Hedw. ) Schimp. & Bryaceae & KPT, Deomali \\
\hline Brachythecium albicans (Hedw.) Schimp. & Bryaceae & SGD, Khandadhar \\
\hline Bryum apiculatum Schwagr. & Bryaceae & CTC, Mahanadi river bed \\
\hline Bryum argenteum Hedw. & Bryaceae & All sites \\
\hline $\begin{array}{l}\text { Bryum argenteum var. lanatum (P. Beauv.) } \\
\text { Hampe }\end{array}$ & Bryaceae & GJM, Chilika \\
\hline Bryum capillare Hedw. (Plate 1: Fig.18) & Bryaceae & KPT, Deomali, GPT, Mahendragiri \\
\hline Bryum cellulare Hook. & Bryaceae & RGD, Baphlimali \\
\hline Bryum coronatum Schwagr. (Plate 1: Fig.19) & Bryaceae & RGD, Baphlimali. KPT, Deomali, RGD, Niyamgiri \\
\hline Bryum plumosum Dozy \& Molk. & Bryaceae & MBNJ, Similipal \\
\hline Campylopus ericoides (Griff.) A. Jaeger & Leucobryaceae & MBNJ, Similipal, KPT, Deomali, GPT, Mahendragiri \\
\hline Campylopus gracilis (Mitt.) A. Jaeger & Leucobryaceae & KPT, Deomali, GPT, Mahendragiri \\
\hline $\begin{array}{l}\text { Cyathophorella hookeriana (Griff.) M. } \\
\text { Fleisch. }\end{array}$ & Cyathophoraceae & KPT, Deomali \\
\hline $\begin{array}{l}\text { Cyathophorum adiantum (Griff.) Mitt. (Plate } \\
\text { 1: Fig.11) }\end{array}$ & Cyathophoraceae & KPT, Deomali \\
\hline
\end{tabular}


Table 1: Checklist of Bryophytes of Odisha (Contd.)

\begin{tabular}{|c|c|c|}
\hline Name of the species & Family & Distribution in Odisha \\
\hline Dicranella heteromalla (Hedw.) Schimp. & Dicranaceae & KPT, Deomali \\
\hline Distichophyllum schmidtii Broth. & Hookeriaceae & MBNJ, Similipal \\
\hline Entodon flavescens (Hook.) A. Jaeger & Entodontaceae & MBNJ, Similipal \\
\hline Entodon plicatus Müll. Hal. & Entodontaceae & KPT, Deomali \\
\hline $\begin{array}{l}\text { Entodontopsis wightii (Mitt.) W.R. Buck \& } \\
\text { R.R. Ireland }\end{array}$ & Entodontaceae & KPT, Deomali \\
\hline Erpodium mangiferae Müll. Hal. & Erpodiaceae & RGD, Baphlimali \\
\hline $\begin{array}{l}\text { Erythrodontium julaceum (Hook. ex } \\
\text { Schwagr.) Paris }\end{array}$ & Erpodiaceae & GPT, Mahendragiri \\
\hline $\begin{array}{l}\text { Eurhynchium muelleri (A. Jaeger) EB } \\
\text { Bartram }\end{array}$ & Brachytheciaceae & KRD, RPRC Campus Orchid Garden, Bhubaneswar \\
\hline Eurhynchium striatulum (Spruce) Schimp. & Brachytheciaceae & GJM, Budhhakhol \\
\hline $\begin{array}{l}\text { Fissidens ceylonensis Dozy \& Molk., (Plate 1: } \\
\text { Fig.27) }\end{array}$ & Fissidentaceae & KHND, Karlapat \\
\hline $\begin{array}{l}\text { Fissidens sylvatus var. zippenlianus } \\
\text { Gangulee }\end{array}$ & Fissidentaceae & BGD, Gandhamardan \\
\hline Fissidens sylvatus var. calcuttense Gangulee & Fissidentaceae & RGD, Baphlimali \\
\hline Fissidens bryoides Hedw. & Fissidentaceae & KJR, Khandadhar, SGD, Khandadhar \\
\hline Fissidens crenulatus Mitt. & Fissidentaceae & KHND, Karlapat, KJH, Khandadhar, KPT, Deomali \\
\hline Fissidens crispulus Brid. & Fissidentaceae & KPT, Deomali \\
\hline Fissidens diversifolius Mitt. & Fissidentaceae & RGD, Baphlimali \\
\hline Fissidens incurvus Starke ex Rohl. & Fissidentaceae & RGD, Baphlimali \\
\hline Fissidens intromarginatulus E.B. Bartram & Fissidentaceae & RGD, Baphlimali \\
\hline Fissidens involutus Wilson ex Mitt. & Fissidentaceae & RGD, Baphlimali \\
\hline Fissidens orishae Gangulee & Fissidentaceae & KPT, Deomali \\
\hline Fissidens schmidii Müll. Hal. & Fissidentaceae & MBNJ, Similipal \\
\hline Fissidens serratus Müll. Hal. & Fissidentaceae & GPT, Mahendragiri \\
\hline Fissidens serrulatus Brid. & Fissidentaceae & GPT, Mahendragiri \\
\hline Fissidens sylvaticus Griff. & Fissidentaceae & GPT, Mahendragiri \\
\hline Fissidens taxifolius Hedw. & Fissidentaceae & KPT, Deomali \\
\hline $\begin{array}{l}\text { Floribundaria walkeri (Renauld \& Cardot) } \\
\text { Broth. }\end{array}$ & Meteoriaceae & KJR, Khandadhar \\
\hline $\begin{array}{l}\text { Foreauella orthothecia (Schwagr.) Dixon \& } \\
\text { P. de la Varde }\end{array}$ & Sematophyllaceae & KJR, Khandadhar \\
\hline Funaria hygrometrica Hedw. & Funariaceae & All sites \\
\hline $\begin{array}{l}\text { Funaria hygrometrica var. calvescens } \\
\text { (Schwagr.) Mont. }\end{array}$ & Funariaceae & MBNJ, Similipal, KPT, Deomali \\
\hline Grimmia funalis (Schwagr.) Bruch \& Schimp. & Grimiaceae & KPT, Deomali \\
\hline $\begin{array}{l}\text { Grimmia indica (Dixon \& P. de la Varde) } \\
\text { Goffinet \& Greven }\end{array}$ & Grimiaceae & KPT, Deomali, Mahendragiri, GPT \\
\hline $\begin{array}{l}\text { Herpetineuron toccoae (Sull. \& Lesq.) } \\
\text { Cardot (Plate 1: Fig.21) }\end{array}$ & Sematophyllaceae & All sites \\
\hline Himantocladium plumula (Nees) M. Fleisch. & Neckeraceae & BGD, Gandhamardan \\
\hline $\begin{array}{l}\text { Hydrogonium arcuatum (Griff.) Wijk \& } \\
\text { Margad. }\end{array}$ & Pottiaceae & BGD, Gandhamardan \\
\hline $\begin{array}{l}\text { Hydrogonium consanguineum (Thwaites \& } \\
\text { Mitt.) Hilp. }\end{array}$ & Pottiaceae & KPT, Deomali \\
\hline
\end{tabular}


Table 1: Checklist of Bryophytes of Odisha (Contd.)

\begin{tabular}{|c|c|c|}
\hline Name of the species & Family & Distribution in Odisha \\
\hline Hymenostomum edentulum (Mitt.) Besch. & Meteoriaceae & KPT, Deomali \\
\hline Hyophila comosa Dixon & Pottiaceae & GPT, Mahendragiri; KPT, Deomali \\
\hline $\begin{array}{l}\text { Hyophila involuta (Hook.) A. Jaeger (Plate 1: } \\
\text { Fig.2) }\end{array}$ & Pottiaceae & GPT, Mahendragiri; KPT, Deomali \\
\hline Hyophila nymaniana (M. Fleisch.) M. Menzel & Pottiaceae & KPT, Deomali \\
\hline Hyophila rosea R.S. Williams & Pottiaceae & KPT, Deomali \\
\hline Hypnum cupressiforme Hedw. & Hypnaceae & RGD, Niyamgiiri, MBNJ, Similipal \\
\hline Isopterygium micans (Sw.) Kindb. Verd. & Hypnaceae & MBNJ, Similipal, KPT, Deomali \\
\hline $\begin{array}{l}\text { Leucobryum juniperoideum (Brid.) Müll. Hal. } \\
\text { (Plate 1: Fig.16) }\end{array}$ & Dicranaceae & GPT, Mahendragiri; KPT, Deomali \\
\hline $\begin{array}{l}\text { Macromitrium sulcatum (Hook.) Brid. (Plate } \\
\text { 1: Fig.20) }\end{array}$ & Orthotrichaceae & GPT, Mahendragiri \\
\hline $\begin{array}{l}\text { Meteoriopsis reclinata (Mull. Hal.) M. } \\
\text { Fleisch. }\end{array}$ & Meteoriaceae & SGD, Khandadhar \\
\hline $\begin{array}{l}\text { Meteoriopsis squarrosa (Hook. ex Harv.) M. } \\
\text { Fleisch. }\end{array}$ & Meteoriaceae & KJR, Khandadhar \\
\hline Neckeropsis crinita (Griff.) M. Fleisch. & Neckeraceae & KPT, Deomali \\
\hline $\begin{array}{l}\text { Neckeropsis exserta (Hook. ex Schwagr.) } \\
\text { Broth. }\end{array}$ & Neckeraceae & KPT, Deomali \\
\hline Octoblepharum albidum Hedw. & Leucobryaceae & KPT, Deomali, GPT, Mahendragiri, MBNJ, Similipal \\
\hline $\begin{array}{l}\text { Oxystegus tenuirostris (Hook. \& Taylor) } \\
\text { A.J.E. Sm. }\end{array}$ & Pottiaceae & BGD, Gandhamardan \\
\hline Papillaria crocea (Hampe) A. Jaeger & Meteoriaceae & SGD, Khandadhar \\
\hline Philonotis falcata (Hook.) Mitt. & Bartramiaceae & GJM, Budhhakhol \\
\hline Philonotis fontana (Hedw.) Brid. & Bartramiaceae & KHND, Karlapat \\
\hline $\begin{array}{l}\text { Philonotis mollis (Dozy \& Molk.) Mitt. (Plate } \\
\text { 1: Fig.28) }\end{array}$ & Bartramiaceae & GJM, Budhhakhol \\
\hline Philonotis hastata (Duby) Wijk \& Margad. & Bartramiaceae & MBNJ, Similipal, KPT, Deomali, GPT, Mahendragiri \\
\hline Philonotis thwaitesii Mitt. & Bartramiaceae & MBNJ, Similipal, KPT, Deomali, GPT, Mahendragiri \\
\hline Physcomitrium pyriforme (Hedw.) Hampe & Funariaceae & SGD, Khandadhar \\
\hline Pinnatella alopecuroides (Mitt.) M. Fleisch. & Neckeraceae & MBNJ, Similipal, KPT, Deomali, GPT, Mahendragiri \\
\hline $\begin{array}{l}\text { Pinnatella calcutensis M. Fleisch. (Michx.) } \\
\text { Prosk. }\end{array}$ & Neckeraceae & MBNJ, Similipal, KPT, Deomali, GPT, Mahendragiri \\
\hline $\begin{array}{l}\text { Pogonatum neesii (Mull. Hal.) Dozy. (Plate 1: } \\
\text { Fig.23) }\end{array}$ & Polytrichaceae & GPT, Mahendragiri \\
\hline $\begin{array}{l}\text { Pogonatum microstomum (R. Br. ex } \\
\text { Schwägr.) Brid. }\end{array}$ & Polytrichaceae & MBNJ, Similipal \\
\hline Pohlia flexuosa Harv. & Bryaceae & GPT, Mahendragiri \\
\hline Polytrichum commune Hedw. & Polytrichaceae & KPT, Deomali \\
\hline Polytrichum juniperinum Hedw. & Polytrichaceae & RGD, Baphlimali, KPT, Deomali \\
\hline $\begin{array}{l}\text { Racopilum cuspidigerum (Schwagr.) } \\
\text { Angstrom (Plate 1: Fig.14) }\end{array}$ & Racopilaceae & KPT, Deomali \\
\hline Racopilum orthocarpum Wilson ex Mitt. & Racopilaceae & KPT, Deomali \\
\hline $\begin{array}{l}\text { Rhynchostegiella divaricatifolia (Renauld \& } \\
\text { Cardot) Broth. }\end{array}$ & Brachytheciaceae & KPT, Deomali \\
\hline $\begin{array}{l}\text { Semibarbula orientalis (F. Weber) Wijk \& } \\
\text { Margad. }\end{array}$ & Pottiaceae & KPT, Deomali \\
\hline Splachnobryum indicum Hampe \& Mull. Hal. & Pottiaceae & RGD, Baphlimali \\
\hline
\end{tabular}


Table 1: Checklist of Bryophytes of Odisha (Contd.)

\begin{tabular}{|c|c|c|}
\hline Name of the species & Family & Distribution in Odisha \\
\hline Stereophyllum radiculosum (Hook.) Mitt. & Stereophyllaceae & GPT Mahendragiri \\
\hline $\begin{array}{l}\text { Stereophyllum confusum Ther. (Plate 1: } \\
\text { Fig.24) }\end{array}$ & Stereophyllaceae & KPT, Deomali \\
\hline Stereophyllum wightii (Mitt.) A. Jaeger & Stereophyllaceae & KPT, Deomali \\
\hline Taxiphyllum giraldii (Mull. Hal.) M. Fleisch. & Sematophyllaceae & KPT, Deomali \\
\hline Taxiphyllum taxirameum (Mitt.) M. Fleisch. & Sematophyllaceae & KPT, Deomali \\
\hline Taxithelium nepalense (Schwagr.) Broth. & Sematophyllaceae & KPT, Deomali \\
\hline $\begin{array}{l}\text { Thuidium cymbifoliolum (Müll. Hal.) Paris } \\
\text { (Plate 1: Fig.15) }\end{array}$ & Leucodontaceae & KPT, Deomali \\
\hline Thuidium koelzii H. Rob. & Leucodontaceae & KPT, Deomali \\
\hline Trachyphyllum inflexum (Harv.) A. Gepp & Entodontaceae & RGD, Baphlimali \\
\hline Trachyphyllum jeyporense Ther. \& Dixon & Entodontaceae & KPT, Deomali, RGD, Baphlimali \\
\hline $\begin{array}{l}\text { Trematodon longicollis Michx. (Plate 1: } \\
\text { Fig.25) }\end{array}$ & Bruchiaceae & KJR, Khandadhar \\
\hline Weissia edentula Mitt. & Ditrichaceae & KRD, Barbara \\
\hline $\begin{array}{l}\text { Wilsoniella decipiens var. acutifolia (Dixon) } \\
\text { Wijk \& Margad. }\end{array}$ & Ditrichaceae & KRD, Barbara \\
\hline
\end{tabular}

Abbreviations: MBNJ: Mayurbhanj, SGD, Sundargarh, RGD: Rayagada, KPT: Koraput, KJR: Keonjhar, AGL: Angul, NGD: Nayagarh, KHND: Kalahandi, MGR: Malkangiri, GPT: Gajpati, BGD: Bargarh, CTC: Cuttack, GJM: Ganjam, KRD: Khurda

They are one of the important components in many forest ecosystems and constitute a major part of the biodiversity in moist environments, wetland, and mountain ecosystems (Hallingback and Hotsgetts, 2000).

They are the second largest group of plants, with about 25,000 species worldwide (Buck and Goffinetnet, 2000). Our knowledge on the taxonomy and distribution of bryophytes are far from adequate and still relies on the work done during the last $20^{\text {th }}$ and early $21^{\text {st }}$ centuries. So far, 2489 taxa of bryophytes recorded from India, comprising 1786 species in 355 genera of mosses, 675 species in 121 genera of liverworts and 25 species in six genera of hornworts of which approximately $72 \%$ are mosses, $27 \%$ are liverworts and $1 \%$ hornworts. About 340 species as endemic of which 269 species are of mosses, 67 are of liverworts and 4 are of hornworts (Dandotiya et al., 2011). Out of 133 rare species 78 are of mosses and 53 are liverworts and nearly 14 species are recorded as endangered. The percentage occurrence of mosses in India is quite high when compared to any other plant group. About 27.5\% of the world's mosses and $11.26 \%$ of liverworts are present in India. In India they are distributed in Eastern and Western Himalayas, South India and Central India (Nath and Asthana, 2005).

Being one of the East Indian state Odisha's unique locations in Peninsular India has blessed it with an interesting assemblage of floral and faunal diversity. With an unindented coastline of nearly $480 \mathrm{~km}$, drained by several large and perennial rivers, altitudinal variation from sea level up to 5000 feet above MSL, varied geography and the confluence of two major biogeographic provinces of India-the Eastern Ghats and Chhotanagpur Plateau-make Odisha a rich biodiversity repository. Of the state's total geographical area, $32.33 \%$ is covered with forests. This works out to be about $7.21 \%$ of the India's total forest area (FSI, 2013). The vegetation of Odisha comes under four types: (i) Odisha Semi-evergreen forests (ii) Tropical moist deciduous forests (iii) Tropical drydeciduous forests and (iv) Littoral and Tidal swamp forests. The state is an abode for around 3000 species of plants which includes 138 species of Orchids, 170 species of pteridophytes, 10 species of gymnosperms, 71 species of mangroves and their associates and 7 species of sea grasses. Apart from angiosperms, gymnosperms and pteridophytes lower group of plants like algae, bryophytes and lichens also contribute substantially to the floral richness of the state. But the studies on cryptogams in general and Bryophytes in particular are insufficient as compared to other groups of plants. Except Gangulee's work (Gangulee, 1969-1980) where bryoflora of some parts of the Eastern Ghats in general and a few localities of Odisha state in particular were mentioned, no other researchers have made any attempt to document the bryoflora of the state. The first systematic studies on Bryophytes of Odisha were conducted by Dash et al. (2007) and reported 23 species of bryophytes from Similipal biosphere reserve. Latter Dash and Saxena, 2009 reported 29 species from Khandadhar hills, Dash et al. (2009) reported 31 species from Baphlimali hills of Eastern Ghats. Dash and Saxena (2011) documented the bryoflora 
of Keonjhar district of Odisha and reported 33 species. Nath et al. (2007) reported 28 species of mosses from Amarkantak (MP) and mentioned the range distribution of 7 species from Odisha. Later on, Dandotiya et al. (2011) published a checklist on Bryoflora of India, where he mentioned about the presence of 47 species from Odisha following mainly Gangulee's record. Nath et al. (2011) presented an overview of family Pottiaceae (Bryopsida) in Central India and reported on the distribution of 3 species of mosses from Odisha. Alam et al. (2013) reported 33 species of bryophytes from Similipal Biosphere Reserve with some new additions to the bryoflora reported by Dash et al. (2007). Bansal and Nath (2014) reported 26 species of the genus Bryum from peninsular India and mentioned about the presence of 4 species from Odisha.

\section{Materials and Methods}

In an attempt to document the bryoflora of the state field survey was conducted in some selected biodiversity rich areas in 12 districts of Odisha, namely Mayurbhanj (Similipal Biosphere Reserve), Kalahandi (Karlapat Wild Life Sanctuary), Rayagada (Niyamgiri hills and Baphlimali hills), Angul (Satkoshia Wild Life Sanctuary) Keonjhar and Sundargarh (Khandadhar hills), Koraput (Deomali hills), Gajapati (Mahendragiri hills), Malkangiri (Chitrakonda), Khurda (Barbara RF and RPRC, Campus, Bhubaneswar), Cuttack (Mahanadi river bed), Ganjam (Budhhakhol) and Dhenkanal (Saptasajya and Kapilas hill (Map 1). The study sites include open, dense and scrub forests, grasslands and degraded forests, mining areas, waterfalls, dead logs, old trees and old monuments.

For sample collection, plants were scraped out along with little substrate with the help of sharp edged knife and a small portion of stem bark having good number of plants were peeled off with a sharp knife for the corticolous bryophytes (growing on tree bark). The aquatic, terrestrial and epiphytic bryophytes were collected in the polythene bags and brought to the laboratory, washed and dried. Collected samples are placed properly in standard Herbarium packets (4" $\mathrm{x} 6$ " in size) in dried form. A printed label of 3 " $\times 5$ " size is glued on the front flap of packet with field data. The dried specimens are deposited in the newly created herbarium of Odisha Biodiversity Board, Bhubaneswar (OBB).

Identification of the specimens was based on the gametophytic and sporophytic characters and special features like elaters, rhizoids, sporophyte diameter, etc. using the standard manuals and by referring the literatures of Chopra and Kumar (1988); Kashyap (1929), Kashyap and Chopra (1932); Gangulee (1969 - 1980), Nair et al. (2005), Satisha (2007). The doubtful specimens were identified by matching with the herbarium specimens at National Botanical Research
Institute, Lucknow and Botanical survey of India, Kolkata during the initial stages of the study period and the other and recently collected doubtful specimens are identified by the authors on the basis of available literature.

Ecology of bryoflora: The maximum diversity of Bryophytes was reported in Deomali followed by Similipal as both these areas offer suitable climatic conditions like good rainfall, moderate temperature, encouraging light intensity, high humidity, etc. Other factors such as age and composition of forest, moisture regime and substrate characteristics like $\mathrm{pH}$ and nutrient that are considered decisive for the growth of bryophytes (Rhoades, 1995; Richards, 1996; Gabriel and Bates, 2005) are also amiable in this part of country. Altitude, an important factor related to diversity and distribution pattern of bryophytes is an influential factor in Odisha. The bryophyte diversity is generally negatively correlated with altitude (Gabriel and Bates, 2005), and this is evident here also by the pervasiveness of thalloid species at lower altitude and of leafy forms at higher altitude in the studied areas of Odisha. The bryophyte composition is related to the physiognomy of the forest and hence the distribution of bryophyte in the forest types of Odisha is governed by many factors related to water availability and nature of the forest types. Species like Anthocerous angustus, Conocephalum conicum, Pallavicinia lyellii, Pellia epiphylla, Polytrichum juniperinum and Targionia indica were found between altitudes of $550 \mathrm{~m}$ to $870 \mathrm{~m}$ at places where the forest is of mostly moist deciduous or semi-evergreen having compact canopy. Five species like Riccia trichocarpa, Riccia glauca, Herpetineuron toccoae, Cyathodium cavernarum and Funaria hygrometrica and were collected from the vicinity of mining areas which harbouring dry deciduous forest with more open canopy. Two thalloid species viz. Dumortiera hirsuta and Plagiochasma appendiculatum showed a wide range of morphological variations along the altitudinal gradient among all sites. Spruceanthus semirepandus, Thuidium cymbifoliolum, Thuidium koelzii, Floribundaria walkeri, Macromitrium sulcatum, Hyophila comosa, Hyophila nymaniana, Racopilum cuspidigerum, Racopilum orthocarpum, Campylopus ericoides, Octoblepharum albidum, Entodontopsis wightii, and Bryum coronatum are found in Mahendragiri and Deomali hills above $1200 \mathrm{~m}$ and Hydrogonium consanguineum, Plagiochasma rupestre, Cyathophorum adiantum, Cyathophorella hookeriana usually spotted above $1300 \mathrm{~m}$ from msl. Mosses like Octoblepharum albeidum usually prefer old trees and Mahendragiri hills, Deomali hills and Similipal biosphere reserve are three most important habitats for this species. Other substrates like old rocks, rocks, stones and pebbles provide suitable habitat for many mosses and liverworts like Aerobryopsis longissima, Stereophyllum 
radiculosum, Bryum sp. Meteoriopsis sp. Rhynchostegiella sp. Trematodon longicollis. Annual rainfall above $1500 \mathrm{~mm}$ might also be one of the key environmental factors for a high diversity of epiphytic moss in places like Similipal and Mahendragiri hills.

\section{Result and Discussion}

Diversity: The bryoflora of Odisha consists of 149 species under 76 genera comprising 102 mosses under 23 families and 52 genera, 41 liverworts under 16 families and 22 genera and 6 hornworts under 2 families and 2 genera (Table 1). Among mosses, Fissidentaceae is found to be the dominant family with 16 species followed by Pottiaceae with 14 species and Bryaceae with 12 species and Bartramiaceae and Entodontaceae with 5 and 4 species each are the other dominant families in mosses. Similarly, Ricciaceae outnumbered the liverwort family with 9 species as compared to Aytoniaceae with 8 species and Marchantiaceae with 4 species. Out of 36 species of Riccia reported from India (Singh, 2014), Odisha harbours 8 species showing the availability of favourable conditions for thalloid liverworts.

Distribution pattern: Two hornworts viz. Anthoceros laevis, and Phaeoceros laevis, three liverworts viz. Riccia fluitans, Cyathodium cavernarum, Plagiochasma appendiculatum, and three moss taxa viz. Bryum argenteum, Funaria hygrometrica, and Herpetineuron toccoae are the common species in all the sites studied. Interestingly, 63 species of bryophytes are found alone in Deomali hill of Koraput followed by 3 species in Similipal Biosphere Reserve (SBR), Mayurbhanj; 34 species in Mahendragiri hills of Gajpati; 20 species each in Baphlaimali hill ranges of Rayagada and Khandadhar hills of Keonjhar and Sundargarh districts. Among mosses, Distichophyllum schmidtii, Thuidium cymbifoliolum, Thuidium koelzii, Floribundaria walkeri, Macromitrium sulcatum, Cyathophorum adiantum, Cyathophorella hookeriana, Polytrichum commune, Polytrichum juniperinum, Hyophila comosa, Hyophila nymaniana, Racopilum cuspidigerum, Racopilum orthocarpum can be considered as rare moss taxa for Odisha due to their site specific and limited occurrence. Similarly liverworts viz. Spruceanthus semirepandus, Plagiochasma rupestre, Lophocolea bidentata, Pallavicinia lyellii, Riccia pathankotensis, and Asterella wallichiana may be considered as rare in the studied areas of Odisha.

Moss species viz. Plagiothecium denticulatum, Philonotis thwaitesii, Brachythecium albicans, Cyathophorum adiantum, Neckeropsis exserta, Floribundaria walkeri, Hypnum cupressiforme, Leucobryum juniperoideum, Octoblepharum albidum, Trachyphyllum jeyporense, Fissidens crenulatus, Hyophila involuta and Macromitrium sulcatum; liverworts like
Lophocolea bidentata, Riccardia levieri, Lejeunea discreta, Spruceanthus semirepandus, Frullania squarrosa, etc. preffered to grow in barks of old trees and usually considered as corticolous. Similarly, thalloid forms viz. Plagiochasma appendiculatum, Conocephalum conicum, Cyathodium cavernarum, Targionia indica, Riccia pathankotensis, Riccia glauca, Riccia billardieri, Pallavicinia lyellii, Pellia epiphylla, Notothylas levieri, Metzgeria himalayensis, Marchantia linearis, Marchantia polymorpha, Dumortiera hirsuta, Thuidium cymbifoliolum, Thuidium koelzii, Heteroscyphus argutus, Barbula javanica, Anoectangium stracheyanum, Racopilum cuspidigerum, Racopilum orthocarpum etc. are found to grow on rocks, stones and pebbles and may be considered as rupicolous and saxicolous taxa. Some species preffered to grow in old trees/fallen logs as lignicolous forms. Species like Riccia grows on river banks and roadside cuts/on soil as terricolous form. While Riccia fluitans, Fissidens sp. and Eurhynchium striatulum are the aquatic forms. Trematodon sp., are lignicolous in nature. The epiphytic mosses and liverworts preferred some specific trees like Acronychia pedunculata, Michelia champaca, Drypetes assamica, Glochidion lanceolarium, Litsea glutinosa, Litsea laeta, Litsea monopetala, Neocinnamomum caudatum, Neolitsea cassia, Neolitsea foliosa, Syzygium caryophyllifolium, Syzygium cerasoides, Callicarpa macrophylla Vahl., Machilus macranthus etc., which are mostly found on shola forests above $1000 \mathrm{~m}$ msl.

Moss species viz. Distichophyllum schmidtii, Thuidium cymbifolium, Thuidium koelzii, Macromitrium sulcatum, Polytrichum commune, Polytrichum juniperinum, Pogonatum neesii, Racopilum cuspidigerum, Racopilum orthocarpum, Cyathophorum adiantum, Trematodon longicollis, Eurhynchium striatulum, Philonotis fontana, Cyathophorella hookeriana, Hypnum cupressiforme, Leucobryum juniperoideum, Anoectangium stracheyanum have been reported for the first time in the studied sites. While in case of liverworts Lophocolea bidentata, Spruceanthus semirepandus, Pellia epiphylla, Aneura pinguis, Riccia beyrichiana, Riccia billardieri and Pallavicinia lyellii are the new entries to the region. Hornwort Notothylas levieri is also a new record for the Eastern Ghats.

\section{Conclusion}

Bryophytes are one of the neglected groups of plants in Odisha. Lack of taxonomic expertise and proper information about their diversity, distribution and ecology might be the reason of negligence for these amphibians of plant kingdom. In the past only sporadic work was done by only a few researchers, as a result of that our knowledge regarding bryophytes of this particular region of India is much lesser than the other bryological regions. To fill this lacuna regarding the diversity 
and distribution of these plants, a detailed taxonomic survey and documentation of bryoflora of the state has been performed in present study. The results of this study clearly indicate that earlier explorations related to bryophytes in the state were inadequate and several potential localities remain untouched. The current report of 149 species in the form of a checklist from Odisha is still a meager estimate. This number is only a basic estimate and it would certainly increase after frequent and extensive bryofloristic survey of all regions of this state that will certainly provide many new reports from this potential but neglected state in terms of bryoflora. Neglected areas like Rebena Reserve Forest, Core areas of Similipal (Meghasini, Barhkamara, and Devasthali etc.), Kuldiha wildlife sanctuary, Barbara-Dhuanali RF, South Odisha in general and Ganjam, Rayagada and Malkangiri district in particular should be given priority for future bryfloristic explorations. Due to inaccessibility, time constrain and lack of funding these areas could not be accessed thoroughly during the present bryofloristic survey. Also, seasonal visits to forests immediately after the rains have to be done because they are also helpful in locating the epiphytic forms, as many of which disappear from the forest on the onset of the dry season.

Generally, the conservation measures have been taken in India mainly for the higher plants. In the case of lower plant groups, very less importance is given by the taxonomist as well as the policy makers. However, these small plants are also facing the potential risks in the form of habitat loss and ever increasing pollution due to unplanned developmental activities. These issues are mainly societal, and the fate of these special plants is dependent upon the overall conservation strategy that must include these small creations of nature. This preliminary study indicates that many localities of Odisha state are rich in bryophytes. As most of the species are found in the hills and mountains where mining is inevitable, a detailed survey and documentation of the bryoflora is needed before they perish due to anthropocentric land use changes in these ecosystems. Since herbarium for lower plants like bryophytes and lichens are not yet been established in Odisha hence steps must be taken to develop herbaria for the preservation of this rich bryoflora. As habitat replacement is rapidly going on and land use changes are almost inevitable, therefore ex-situ conservation of bryophytes especially focusing on region specific threatened species is essential for their conservation.

\section{Acknowledgements}

The authors are thankful to Dr. Virendra Nath, Head of the Bryology Division, NBRI and Dr. A.K. Asthana, Senior Scientist, NBRI, Lucknow for their guidance and support in identifying the doubtful specimens. Dr.D.K. Saxena, Head, PG Department of Botany, Bareilly Collage, Uttar Pradesh and Dr.D.K. Singh, Additional Director (Former), Botanical survey of India are also highly acknowledged for their contribution towards identification of some mosses and liverworts.

\section{References}

Alam, A., K. K. Behera, S. Vats, and M. Iqbal. 2013. A preliminary study on bryodiversity of Similipal Biosphere Reserve (Odisha), India. Arch Bryol, 157: 1-9.

Bansal, P. and V. Nath. 2014. Genus Bryum Hedw. in Peninsular India. Frahmia 4: 1-11

Buck, W. R. and B. Goffinet. 2000. Morphology and classification of mosses. In: Bryophyte Biology (Shaw A.J. and Goffinet B., eds.), Cambridge University Press. pp.71-123. doi: 10.1017/CBO9781139171304.004

Chopra, R. N and P. K. Kumar. 1988. Biology of bryophytes. Wiley Eastern Limited, New Delhi, India.

Dandotiya, D, H., Govindapyari, S. Shantanu, and P. Uniyal 2011. Checklist of the bryophytes of India. Arch Bryol 88: 1-126

Dash, P. K., S. Sahu, and D. K. Saxena. 2009. Bryoflora of Baphlamali Hills in Eastern Ghats of Orissa, India, EPTRI - ENVIS Newsletter. 15(1):1-8.

Dash, P. K. and D. K. Saxena. 2009. Bryoflora of Khandadhar hill ranges, Orissa, India, Geobios 36: 113-16.

Dash, P. K. and D. K. Saxena. 2011. Bryological flora of Keonjhar district of Odisha, India. Punjab University Research Journal (Science). 61: 153-157.

Dash, P. K., P. K. Mahapatra M. Kar, N.K. Dhal, and N. C. Rout. 2007. Bryoflora of Similipal Biosphere Reserve with special reference to Liverworts and hornworts, Similipal Biosphere Reserve, Orissa, India. Biannual Bulletin of Regional Plant Research Centre 2 (1\&2): 32-37.

Gabriel, R. and J. W. Bates. 2005. Bryophyte community composition and habitat specificity in the natural forests of Terceira, Azores. Plant Ecol 177: 125-144. doi: 10.1007/s11258-005-2243-6

Gangulee, H.C. (1969-1980). Mosses of Eastern India and Adajacent regions. Fascicles 1-8. Books and Allied Limited, Calcutta.

Hallingbäck, T. and N. Hodgetts. 2000. Mosses, liverworts and hornworts. Status survey and conservation action plan for bryophytes- IUCN/SSC Bryophytes Spec. Grp, IUCN, Gland, Switzerland and Cambridge, UK.

India State of Forest Report (ISFR). 2013

Kashyap, S. R. 1929. Liverworts of western Himalayas and Panjab plains. Vol. 1, University of Panjab, Lahore. 129 Pp.

Kashyap, S. R., and R. N. Chopra. 1932. Liverworts of western Himalayas and Panjab plains. Vol. 2 , University of Panjab, Lahore. 137 pp.

Nair, M. C. and P.V. Madhusoodanan. 2005. Studies on the bryophyte flora of Kerala (South India) - An introduction. J Econ Tax Bot 26: $697-708$.

Nath, V. and A. K. Asthana. 2005. Studies on Indian Bryophytes. 50 years of National Botanical Research Institute. pp. 277-288.

Nath, V., A. K Asthana and R. Kapoor. 2007. Enumeration of the mosses in Amarkantak (Madhya Pradesh) India. Tawania 52(2): 168176.

Nath, V., A. K. Asthana, and R. Gupta. 2011. An overview of family Pottiaceae (Bryopsida) in central India with special reference to Pachmarhi Biosphere Reserve (PBR) Lindbergia 34, pp. 3039.

Rhoades, F. M. 1995. Nonvascular epiphytes in Forest Canopies: Worldwide distribution, Abundance and ecological Roles. Forest Canopies. Academic Press, New York.

Richards, P.W., 1996. The Tropical Rain Forest; an Ecological Study. $2^{\text {nd }}$ edn. Cambridge University Press, Cambridge.

Sathisha, A. M. 2007. Survey and Documentation of Bryophytes in Bhadra Wildlife sanctuary, Karnataka. Ph.D.Thesis. Kuvempu University.

Singh, S.K., 2014. An Appraisal of Genus Riccia in India with a Note on Diversity and Distribution of Species. Int J Sustain Water and Environ Syst 6(1): $35-43$. 